SUSTAINABLE FORESTRY

COLLECTION 65-66, 2012
ODRŽIVO ŠUMARSTVO

ZBORNIK RADOVA 65-66, 2012

UDK $630 * 114.6(497.11$ Beograd $)=111$

Original scientific paper

\title{
MICROBIOLOGICAL ACTIVITY OF THE FOREST SOIL IN THE AREAS WITHIN THE TERRITORY OF BELGRADE
}

\author{
Milorad VESELINOVIĆ ${ }^{1}$, Vesna GOLUBOVIĆ-ĆURGUZ ${ }^{2}$, Suzana MITROVIĆ ${ }^{1}$, \\ Dragana DRAŽIĆ ${ }^{1}$, Nevena ČULE ${ }^{1}$, Biljana NIKOLIĆ ${ }^{1}$, Đorđe JOVIĆ ${ }^{1}$
}

\begin{abstract}
Within the process of matter circulation, soil microorganisms play a decisive role in the biological circulation of nutrition elements, i.e. plant assimilatives, through the process of organic matter (detritus) degradation via biosynthesis (humification) and mineralization (dehumification), releasing plant assimilatives and thus enabling forests to survive as natural ecosystems. Development of appropriate physiological groups of microorganisms participating in such processes and their biological activity are prerequisites of forest ecosystem stability. The results of the research in microbiological activity of the forest soil conducted in the areas within the territory of Belgrade include 19 locations of forested areas in both state and private ownership. Preliminary research suggested that the process of ammonification is by far the most significant in both synthesis and degradation of humus for plant assimilative formation (nitrogen, phosphorus, sulphur etc.); therefore the measures undertaken must be focused on ensuring normal and regular course of such processes.
\end{abstract}

Key words: forest soil, ammonifying microorganisms, oligonitrofilic microorganisms, actinomycetes.

\footnotetext{
${ }^{1}$ Forestry Institute, Belgrade, e-mail:mvcetiri@ikomline.net

${ }^{2}$ Faculty of Forestry, University of Belgrade

*The paper is the result of the studies conducted in the framework of projects (period 20112014) of the Republic of Serbia Ministry of education, Science and Tehnological Tevelopement and City of Belgrade Secretariat for Environmental Protection
} 


\title{
MIKROBIOLOŠKA AKTIVNOST ŠUMSKIH ZEMLJIŠTA NA PODRUČJU BEOGRADA
}

\begin{abstract}
Abstrakt: $U$ procesu kruženja materije zemljišni mikroorganiozmi imaju odlučujuću ulogu u biološkom kruženju elemenata ishrane - biljnih asimilativa kroz proces degradacije organske materije (stelje) biosintezom (humifikacijom) $i$ mineralizacijom (dehumifikacijom) oslobađajući biljne asimilative i time omogućavajući šumi da opstane kao prirodni ekosistem. Razvoj odgovarajućih fizioloških grupa mikroorganizama koji učestvuju u ovim procesima $i$ njihova biološka aktivnost je predpostavka stabilnosti šumskih ekosistema. Rezultati istraživanja mikrobiološke aktivnosti šumskih zemljišta koja su vršena na području Beograda obuhvataju 19 lokaliteta pod šumom u državnom $i$ privatnom vlasništvu. Preliminarna istraživanja ukazuju da je proces amonifikacije, najznačajniji kako u sintezi tako i u razlaganju humusa za stvaranje biljnih asimilativa (azota, fosfora, sumpora $i$ dr.), pa i mere koje se primenjuju moraju biti usmerene da se ovakvi procesi odvijaju normalno.
\end{abstract}

Ključne reči: šumsko zemljište, amonifikaconi mikroorganizmi, oligonitrofilni mikroorganizmi, aktinomicete.

\section{INTRODUCTION}

Through their activity microorganisms enable today's living communities - biocenoses - to live as they are indispensable members of such communities (Varman, A.H., Evans, M.G., 2000).

Green plants create organic matter from inorganic compounds and they are producers. Animals consume the created organic matter and they are consumers. Microorganisms slowly degrade the created organic matter and create mineral compounds - plant assimilatives - necessary for the nutrition of plants and they are destroyers - reducers. This type of activity of microorganisms is called organic matter mineralization. It is the principal role of microorganisms in nature and it provides closure to the process of matter and energy circulation. Circulation itself is the material basis of all life in nature as thereby insignificant quantities of certain elements and compounds (carbon, nitrogen, phosphorus and others) are made infinite once they are introduced in the matter circulation process in nature (Sylvia, D.M.et. al., 2005, Tešić, Ž., 1968).

As natural plant ecosystems, forests rely on the natural processes of matter and energy circulation for their survival and development. Within such processes, soil microorganisms play a decisive role in the biological circulation of nutrition elements, i.e. plant assimilatives, through the process of organic matter (detritus) degradation via biosynthesis (humification) and mineralization (dehumification), releasing plant assimilatives and thus enabling forests to survive as natural ecosystems (Raičević, V. et al. 2010, Tešić, Ž., 1968). Humification refers to the biochemical and microbiological processes wherein fresh organic matter within the soil (forest litterfall) is converted into new humus matter of a colloidal nature. The course of humification and the nature of humus depend on the chemical composition. Such processes take place in a very dynamic soil environment and environmental conditions have a significant impact on the qualitative and 
quantitative composition of the microflora, the type of humification products and the course of humification (Atlas, R.M. et al., 1991, Mišustin, E.N., 1956). Development of appropriate physiological groups of microorganisms participating in such processes and their biological activity are prerequisites of the forest ecosystem stability. Their function in certain forest soil types with varying anthropogenic influence is a significant stability factor for such soils.

\section{MATERIALS AND METHODS}

Most forests in the territory of Belgrade belong to the PosavskoPodunavski forest region, which is managed by Forest Estate Belgrade, whereof $16,686.70$ hectares are state-owned and 15,636 hectares are privately owned. A portion of forests in the territory of Lazarevac Municipality belong to the Podrinjsko-Kolubarski forest region, which is managed by the Forest Estate Boranja-Loznica, whereof 379.37 hectares are state-owned and 6,172 hectares are privately owned. From May 2010 to April 2011, research in microbiological activity of forest soil was conducted at 19 locations of forested areas in both state and private ownership in the territory of Belgrade (Figure 1).

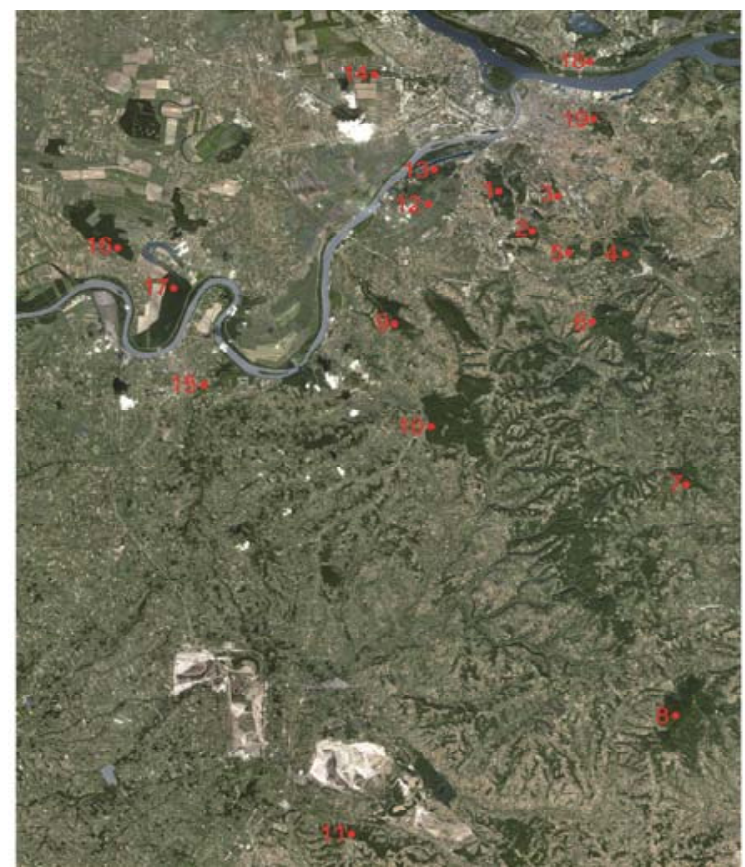

Figure 1. Overview of locations where research was conducted

1. Košutnjak - of deciduous species Turkey oak has a predominant share accompanied by large-leaved lime and silver lime, hornbeam and English oak, whereas the share of coniferous species is only $5 \%$.

2. Miljakovačka šuma - poorly cultivated stands with lush and bushy stand understorey without internal open spaces. 
3. Banjička šuma - belongs to the habitat of a potential ceno-ecological type of forest of English oak, hornbeam, Turkey oak and lime.

4. Stepin lug-Jajinci - dominant pure and mixed stands of black locust.

5. Baba Velka - mixed stands of deciduous trees (32\%), mixed stands of coniferous trees $(30 \%)$, pure stands of deciduous trees $(23 \%)$, pure stands of coniferous trees $(6 \%)$ and stands of mixed deciduous and conifers (only $1 \%)$.

6. Avala - most present tree species is sessile oak, which covers about $20 \%$ of the area of all forests.

7. Trešnja - the largest share is that of mixed stands of sprout origin (48\%).

8. Kosmaj $-79.32 \%$ of the forest area is covered by forests of sprout origin, whereas the share of tall deciduous tree forests is only $1.96 \%$ of the area.

9. Sremački rt sa Goricom - Turkey oak and Hungarian oak stands of sprout origin prevail here, followed by sprout origin stands of black locust and anthropogenic-originated stands of conifers (black pine and spruce) and deciduous trees (English oak and O.T.L.).

10. Lipovica - mixed deciduous stands of sprout origin prevail and there are, to a less extent, pure black locust stands of sprout origin.

11. Lazarevačke šume - most present of deciduous trees in this municipality are beech and Turkey oak and of conifers - black pine.

12. Makiš - both natural and anthropogenic deciduous forests.

13. Ada Ciganlija - these are mostly second generation stands of sprout origin, with only a very small share of Euro-American poplar.

14. Šume uz autoput (Forests alongside the highway) - are of anthropogenic origin with a wide range of autochthonous and allochthonous deciduous and coniferous species.

15. Obrenovački zabran - predominant sprout mixed stands of narrow-leafed ash and English oak, sprout mixed stands of willows and poplars and anthropogenic stands of I-214 and red oak.

16. Bojčinska šuma - predominant are anthropogenic tall English oak stands, both pure and mixed.

17. Crni lug - mostly comprised of stands of narrow-leafed ash and English oak as well as of poplar and black locust.

18. Ritske šume - predominant are anthropogenic stands - plantations of Euro-American poplar, which cover about $90 \%$ of the area according to data from the special records.

19. Zvezdarska šuma - deciduous and coniferous forests of anthropogenic origin.

During the months of analyses, sampling was conducted two times from three sites at each location and the averages thereof were analyzed in terms of presence of microorganisms as significantly indicative of soil activity in the forest ecosystems. The objective of the research was to determine the dynamics of the processes within the soil at the selected locations within forest ecosystems in the territory of Belgrade.

Field substrate sampling - at the selected locations the substrate for microbiological analysis was sampled two times in certain months whereby three 
samples were collected each time from the depth within the detritus zone (up to 10 $\mathrm{cm}$ ) in the stands with formed detritus; at other sites, samples were collected from the depth of $10-20 \mathrm{~cm}$. The samples collected were packed in bags, labeled and placed in refrigerators in order to be prepared for laboratory analyses within 24 hours.

Substrate preparation under laboratory conditions - each month soil samples were collected from the 19 locations for determination of the total number of microorganisms present. This was achieved by cultivating soil suspension of 0.1 $\mathrm{ccm}$ in $10^{-3}$ dilution on nutritive base media. Cultivation was performed in three repetitions, and the number of microorganisms was calculated per 1gr of absolutely dry soil.

Nutritive base preparation for cultivation of soil suspension - in laboratory investigation four different nutritive bases were used: Czapek's agar, MPA (meat peptonic agar), Ashby's agar and synthetic agar. The base media used are of the following compositions:

\begin{tabular}{|c|c|c|c|c|c|c|c|}
\hline \multicolumn{2}{|c|}{ Czapek's agar } & \multicolumn{2}{|c|}{$\begin{array}{c}\text { Synthetic agar with } \\
\text { saccharose }\end{array}$} & \multicolumn{2}{|c|}{ MPA agar } & \multicolumn{2}{|c|}{ Ashby's agar } \\
\hline $\mathrm{N}_{\mathrm{a}} \mathrm{NO}_{3}$ & $3.0 \mathrm{gr}$ & $\mathrm{KH}_{2} \mathrm{PO}_{4}$ & $0.5 \mathrm{gr}$ & nutritive agar & $41.3 \mathrm{gr}$ & $\mathrm{KH}_{2} \mathrm{PO}_{4}$ & $0.2 \mathrm{gr}$ \\
\hline $\mathrm{KH}_{2} \mathrm{PO}_{4}$ & $1.0 \mathrm{gr}$ & $\mathrm{MgCO} 3$ & $0.50 \mathrm{gr}$ & (Torlak, & & $\mathrm{MgSO}_{4}$ & $0.2 \mathrm{gr}$ \\
\hline $\mathrm{KCl}$ & $0.50 \mathrm{gr}$ & $\mathrm{NaCl}$ & $0.5 \mathrm{gr}$ & Belgrade) & up to & $\mathrm{NaCl}$ & $0.2 \mathrm{gr}$ \\
\hline $\mathrm{MgSO}_{4}$ & $0.50 \mathrm{gr}$ & $\mathrm{KNO}_{3}$ & $1.0 \mathrm{gr}$ & distilled water & $1000 \mathrm{ml}$ & $\mathrm{K}_{2} \mathrm{SO}_{4}$ & $0.1 \mathrm{gr}$ \\
\hline $\mathrm{FeSO}_{4}$ & $0.01 \mathrm{gr}$ & $\mathrm{FeSO}_{4}$ & $0.01 \mathrm{gr}$ & & & $\mathrm{CaCO}_{3}$ & $5.0 \mathrm{gr}$ \\
\hline Agar & $20.0 \mathrm{gr}$ & $\mathrm{CaCO}_{3}$ & in excess & (1 liter of the $b$ & e contains: & Agar & $20.0 \mathrm{gr}$ \\
\hline Saccharose & $3.0 \mathrm{gr}$ & Agar & $20.0 \mathrm{gr}$ & peptone $15.0 \mathrm{~g}$ & bovril 3.0 & Maltose & $20.0 \mathrm{gr}$ \\
\hline Distilled & up to & Saccharose & $25.0 \mathrm{gr}$ & $\mathrm{gr}, \mathrm{NaCl} 5.0 \mathrm{~g}$ & otassium & (Glucose) & \\
\hline water & $1000 \mathrm{ml}$ & $\begin{array}{l}\text { Distilled } \\
\text { water }\end{array}$ & $\begin{array}{l}\text { up to } \\
1000 \mathrm{ml}\end{array}$ & $\begin{array}{l}\text { hydrogen phos } \\
\text { agar } 18 \mathrm{gr} \text { ) }\end{array}$ & ate $0.3 \mathrm{gr}$, & $\begin{array}{l}\text { Distilled } \\
\text { water }\end{array}$ & $\begin{array}{l}\text { up to } \\
1000 \mathrm{ml}\end{array}$ \\
\hline
\end{tabular}

Nutritive bases were autoclaved at the temperature of $120^{\circ} \mathrm{C}$ and pressure of $1.5 \mathrm{~atm}$ for 20 minutes. Subsequent to sterilization, the nutritive bases were poured into Petri dishes. In each Petri dish, soil suspension of $0.1 \mathrm{~cm}$ in $10^{-3}$ dilution was added to $25 \mathrm{ml}$ of the nutritive base. All Petri dishes were placed in a thermostat at the temperature of $22 \pm 1^{\circ} \mathrm{C} .5$ and 10 days later, total respective numbers of fungi, bacteria and actinomycetes developed on the nutritive media were determined. Data on the numbers of microorganisms were then calculated per $1 \mathrm{gr}$ of air dried soil, so that the numbers of the principal physiological groups of soil microorganisms were expressed in the units of $1,000 \mathrm{pcs} / 1 \mathrm{gr}$ of dry soil. Measurement data obtained per month were calculated into average values for each month analyzed and presented in tables as such.

\section{RESULTS AND DISCUSSION}

\subsection{Total number of ammonifying microorganisms}

Ammonifying microorganisms are among most significant physiological groups present in the soil. They participate in degradation of proteins thus releasing nitrogen (one of the essential elements for plant nutrition) from organic matter, converting it into more accessible forms. Degradation of organic matter through the activity of these microorganisms releases ammonia but only in the instances of 
sufficiently low $\mathrm{C} / \mathrm{N}$ ratio within the organic matter. Otherwise almost all ammonia is used by the microorganisms for their own cell protoplasm synthesis; they partially comprise humus. At a number of locations the maximum numbers of these microorganisms were reached in September, whereas the minimum numbers were recorded in May. Large numbers were identified in autumn and winter months, from September to January. This was due to mild winter with daily temperatures above $0^{\circ} \mathrm{C}$, ranging from +10 to $+20^{\circ} \mathrm{C}$, and precipitation which allowed sufficient moisture. The largest numbers of ammonifying microorganisms were recorded in the soil of deciduous forests in Banjica, Baba Velka, Jajinci, on Avala and in Lipovica. In the soil of anthropogenic forest parks such as Košutnjak, Miljakovac, Makiš, Ada Ciganlija, Avala and alongside the highway, the numbers of these microorganisms were significantly lower, as was the case in Obrenovački zabran, with predominant poplar trees. In Banjičke šume, Crni Lug (oak forests), Ritske šume, Trešnja and on Kosmaj (coniferous forests), the numbers of these microorganisms were significantly lower. This means that ammonification processes in organic matter degradation are depressed and inflow of plant assimilatives reduced. At such locations, these processes were influenced by vegetation (Table 1).

Table 1. Total number of bacteria on MPA agar (1000 pcs / $1 \mathrm{~g}$ of dry soil)

\begin{tabular}{|l|r|r|r|r|r|c|}
\hline Locations & \multicolumn{1}{|c|}{ July } & September & October & November & January & May \\
\hline Kosutnjak & 15.01 & 10.51 & 34.01 & 33.67 & 28.32 & 37.79 \\
\hline Miljakovac & 15.62 & 68.19 & 26.26 & 39.87 & 40.67 & 34.86 \\
\hline Banjica & 43.88 & 74.90 & 30.29 & 35.66 & 42.62 & 59.00 \\
\hline Baba Velka & 30.26 & 60.14 & 26.58 & 44.98 & 59.29 & 38.81 \\
\hline Jajinci & 38.64 & 30.76 & 29.77 & 32.45 & 23.12 & 61.43 \\
\hline Avala & 21.88 & 33.02 & 39.40 & 53.14 & 37.09 & 44.01 \\
\hline Tresnja & 19.27 & 20.59 & 17.18 & 36.93 & 20.83 & 36.40 \\
\hline Kosmaj & 16.39 & 30.50 & 41.06 & 25.59 & 16.56 & 29.40 \\
\hline Gorica & 15.48 & 44.16 & 13.86 & 31.22 & 52.55 & 19.98 \\
\hline Lipovica & 39.05 & 87.55 & 41.56 & 45.88 & 38.44 & 17.40 \\
\hline Laz.sume & 36.43 & 41.20 & 19.48 & 22.37 & 30.33 & 66.88 \\
\hline Makis & 14.83 & 4.38 & 37.29 & 61.60 & 41.43 & 20.75 \\
\hline Ada Ciganlija & 16.00 & 26.74 & 20.46 & 58.62 & 114.80 & 73.92 \\
\hline Auto put & 17.28 & 29.81 & 23.19 & 51.53 & 35.21 & 43.78 \\
\hline Obrenovacki zabran & 14.09 & 41.57 & 30.29 & 71.04 & 26.73 & 65.95 \\
\hline Bojcin & 17.85 & 35.65 & 19.91 & 80.19 & 34.15 & 70.97 \\
\hline Crni lug & 18.86 & 53.48 & 63.44 & 57.47 & 44.17 & 64.16 \\
\hline Ritske sume & 17.17 & 39.63 & 49.24 & 75.95 & 56.44 & 81.81 \\
\hline Zvezdara & 15.64 & 42.49 & 54.84 & 34.71 & 35.86 & 44.98 \\
\hline
\end{tabular}




\subsection{Total number of oligonitrofilic microorganisms}

Microorganisms of this physiological group are satisfied with small quantities of nitrogen from the degraded organic matter as they have the ability to partially compensate for the lack of accessible nitrogen from the atmosphere through nitrogen fixation. This means that this physiological group, via the synthesis of its microbiological substance, introduces atmospheric nitrogen into the biological circulation. The number of bacteria (Table 2) from the group of oligonitrofililic microorganisms is rather subject to variation; however, it was observed that numbers rise at those locations where the numbers of ammonifying microorganisms are lower. In September and May these bacteria were not identified at the following locations: Banjica, Baba Velka, Jajinci, Trešnja, Kosmaj, Lipovica and Lazarevačke šume.

Table 2. Total number of bacteria on Ashby's agar (1000 pcs / 1 g of dry soil)

\begin{tabular}{|l|r|r|r|r|r|r|}
\hline Locations & \multicolumn{1}{|c|}{ July } & September & October & November & January & \multicolumn{1}{c|}{ May } \\
\hline Kosutnjak & \multicolumn{1}{|c|}{36.82} & 42.05 & 11.73 & 38.18 & 9.01 & 6.99 \\
\hline Miljakovac & 21.60 & 20.32 & 12.60 & 15.93 & 5.11 & 6.45 \\
\hline Banjica & 42.63 & 0.00 & 21.31 & 17.24 & 0.00 & 3.93 \\
\hline Baba Velka & 39.89 & 35.43 & 35.82 & 1.08 & 0.00 & 4.31 \\
\hline Jajinci & 17.56 & 0.00 & 0.00 & 18.07 & 0.00 & 8.38 \\
\hline Avala & 21.88 & 0.00 & 8.75 & 1.36 & 9.27 & 8.56 \\
\hline Tresnja & 25.58 & 0.00 & 13.74 & 23.63 & 0.00 & 8.49 \\
\hline Kosmaj & 24.58 & 0.00 & 17.96 & 16.56 & 6.01 & 10.23 \\
\hline Gorica & 26.19 & 0.00 & 9.24 & 22.29 & 0.00 & 0.00 \\
\hline Lipovica & 10.12 & 0.00 & 56.22 & 0.00 & 0.00 & 13.38 \\
\hline Laz.sume & 28.15 & 0.00 & 52.71 & 5.97 & 17.14 & 0.00 \\
\hline Makis & 51.92 & 41.6 & 24.86 & 48.77 & 58.31 & 34.57 \\
\hline Ada Ciganlija & 0.00 & 20.32 & 59.11 & 16.91 & 19.52 & 40.32 \\
\hline Auto put & 11.52 & 6.39 & 40.85 & 21.47 & 50.99 & 3.75 \\
\hline Obrenovacki zabran & 7.04 & 20.78 & 15.15 & 22.05 & 52.06 & 10.41 \\
\hline Bojčin & 24.72 & 7.95 & 44.50 & 43.49 & 13.01 & 48.71 \\
\hline Crni lug & 15.09 & 51.79 & 58.15 & 25.86 & 69.02 & 45.38 \\
\hline Ritske sume & 4.29 & 26.42 & 17.30 & 13.32 & 22.88 & 56.14 \\
\hline Zvezdara & 24.06 & 4.26 & 35.76 & 20.57 & 29.61 & 44.98 \\
\hline
\end{tabular}

Numbers of fungi (Table 3) and bacteria (Table 2) varied immensely according to the weather and locations. Fungi were present in significant numbers and, together with bacteria from this group, suggested the lack of nitrogen in accessible form within the organic matter in the soil; on the other hand, such lack of nitrogen was compensated in certain amount with the nitrogen from the 
atmosphere through nitrogen fixation, which increased the inflow of plant assimilatives.

Table 3. Total number of fungi on Ashby's agar (1000 pcs / $1 \mathrm{~g}$ of dry soil)

\begin{tabular}{|l|r|r|r|r|r|r|}
\hline Locations & \multicolumn{1}{|c|}{ July } & September & October & November & January & \multicolumn{1}{c|}{ May } \\
\hline Kosutnjak & \multicolumn{1}{|c|}{36.82} & 12.85 & 23.45 & 25.45 & 20.59 & 48.93 \\
\hline Miljakovac & 44.26 & 22.34 & 7.35 & 14.79 & 21.73 & 27.11 \\
\hline Banjica & 22.57 & 22.06 & 10.09 & 12.31 & 50.37 & 23.60 \\
\hline Baba Velka & 18.16 & 38.91 & 16.18 & 2.16 & 51.56 & 18.69 \\
\hline Jajinci & 19.90 & 18.23 & 0.0 & 3.87 & 15.03 & 48.86 \\
\hline Avala & 14.16 & 11.79 & 24.07 & 8.17 & 18.77 & 41.56 \\
\hline Tresnja & 45.94 & 28.59 & 20.61 & 23.63 & 7.81 & 26.69 \\
\hline Kosmaj & 15.02 & 32.95 & 23.09 & 12.04 & 13.55 & 34.52 \\
\hline Gorica & 45.25 & 33.12 & 16.88 & 8.92 & 37.34 & 19.98 \\
\hline Lipovica & 33.27 & 53.16 & 15.89 & 18.16 & 28.83 & 53.54 \\
\hline Laz.sume & 62.93 & 29.26 & 16.04 & 5.97 & 22.41 & 36.01 \\
\hline Makis & 9.89 & 20.80 & 28.25 & 15.40 & 16.88 & 42.64 \\
\hline Ada Ciganlija & 56.01 & 0.00 & 21.59 & 24.80 & 28.31 & 52.76 \\
\hline Auto put & 58.75 & 28.75 & 4.42 & 9.66 & 10.93 & 56.29 \\
\hline Obrenovacki zabran & 50.49 & 19.74 & 15.15 & 7.35 & 22.51 & 5.78 \\
\hline Bojcin & 31.59 & 2.26 & 18.74 & 9.51 & 42.28 & 52.88 \\
\hline Crni lug & 54.28 & 21.48 & 26.43 & 27.29 & 9.66 & 35.99 \\
\hline Ritske sume & 61.54 & 1.10 & 31.94 & 10.66 & 13.73 & 73.79 \\
\hline Zvezdara & 26.47 & 4.25 & 45.30 & 11.57 & 10.63 & 29.11 \\
\hline
\end{tabular}

\subsection{Total number of actinomycetes}

Actionmycetes comprise a physiological group of microorganisms that vigorously degrade organic matter and humus up to the end-products of mineralization, thus releasing plant assimilatives. Actionmycetes were not identified on Czapek's agar. They were identified in small numbers only on the synthetic agar (Table 4), at the locations of Košutnjak, Miljakovac, Jajinci, Trešnja, on Kosmaj, in Makiš, Banjička šuma, Ritske šume and Zvezdara.

Table 4. Total number of actinomycetes on Czapek's agar (1000 pcs/lg of dry soil)

\begin{tabular}{|l|r|r|r|r|r|r|}
\hline Locations & \multicolumn{1}{c|}{ July } & September & October & November & January & \multicolumn{1}{c|}{ May } \\
\hline Kosutnjak & 1.36 & 0.00 & 0.00 & 0.00 & 1.28 & 0.00 \\
\hline Miljakovac & 0.00 & 0.00 & 0.00 & 0.00 & 0.00 & 0.00 \\
\hline Banjica & 0.00 & 0.00 & 0.00 & 0.00 & 0.00 & 0.00 \\
\hline Baba Velka & 0.00 & 0.00 & 0.00 & 0.00 & 0.00 & 0.00 \\
\hline Jajinci & 0.00 & 0.00 & 0.00 & 0.00 & 0.00 & 0.00 \\
\hline
\end{tabular}




\begin{tabular}{|l|r|r|r|r|r|c|}
\hline Locations & July & September & October & November & January & May \\
\hline Avala & 0.00 & 0.00 & 0.00 & 0.00 & 19.80 & 0.00 \\
\hline Tresnja & 7.41 & 0.00 & 0.00 & 0.00 & 0.00 & 0.00 \\
\hline Kosmaj & 0.00 & 0.00 & 0.00 & 0.00 & 0.00 & 0.00 \\
\hline Gorica & 5.95 & 0.00 & 0.00 & 0.00 & 0.00 & 0.00 \\
\hline Lipovica & 0.00 & 0.00 & 0.00 & 0.00 & 0.00 & 0.00 \\
\hline Laz.sume & 6.62 & 0.00 & 0.00 & 0.00 & 0.00 & 0.00 \\
\hline Makis & 0.00 & 0.00 & 0.00 & 0.00 & 10.70 & 2.30 \\
\hline Ada Ciganlija & 0.00 & 0.00 & 0.00 & 0.00 & 0.00 & 1.34 \\
\hline Auto put & 0.00 & 0.00 & 0.00 & 0.00 & 0.00 & 0.00 \\
\hline Obrenovacki zabran & 0.00 & 0.00 & 0.00 & 0.00 & 0.00 & 2.31 \\
\hline Bojcin & 0.00 & 0.00 & 0.00 & 0.00 & 0.00 & 5.56 \\
\hline Crni lug & 2.75 & 0.00 & 0.00 & 0.00 & 0.00 & 4.69 \\
\hline Ritske sume & 0.00 & 0.00 & 0.00 & 0.00 & 0.00 & 11.22 \\
\hline Zvezdara & 0.00 & 1.06 & 0.00 & 0.00 & 0.00 & 3.96 \\
\hline
\end{tabular}

Table 5. Total number of actinomycetes on synthetic agar (1000 pcs/lg of dry soil)

\begin{tabular}{|l|r|r|r|r|r|r|}
\hline Locations & July & September & October & November & January & May \\
\hline Kosutnjak & 1.36 & 1.17 & 2.34 & 15.27 & 0.00 & 4.19 \\
\hline Miljakovac & 0.00 & 0.00 & 0.00 & 0.00 & 0.00 & 3.87 \\
\hline Banjica & 6.26 & 0.00 & 3.36 & 0.00 & 0.00 & 0.00 \\
\hline Baba Velka & 0.00 & 0.00 & 0.00 & 0.00 & 0.00 & 0.00 \\
\hline Jajinci & 0.00 & 2.28 & 0.00 & 0.00 & 0.00 & 1.39 \\
\hline Avala & 0.00 & 0.00 & 0.00 & 0.00 & 0.00 & 0.00 \\
\hline Tresnja & 0.00 & 0.00 & 0.00 & 0.00 & 0.00 & 2.42 \\
\hline Kosmaj & 0.00 & 0.00 & 0.00 & 0.00 & 0.00 & 5.11 \\
\hline Gorica & 0.00 & 0.00 & 0.00 & 0.00 & 0.00 & 0.00 \\
\hline Lipovica & 0.00 & 0.00 & 0.00 & 0.00 & 0.00 & 0.00 \\
\hline Laz.sume & 0.00 & 0.00 & 0.00 & 0.00 & 0.00 & 0.00 \\
\hline Makis & 0.00 & 0.00 & 0.00 & 0.00 & 0.00 & 2.30 \\
\hline Ada Ciganlija & 0.00 & 0.00 & 0.00 & 0.00 & 0.00 & 0.00 \\
\hline Auto put & 0.00 & 0.00 & 0.00 & 0.00 & 0.00 & 0.00 \\
\hline Obrenovacki zabran & 0.00 & 0.00 & 0.00 & 0.00 & 0.00 & 0.00 \\
\hline Bojcin & 0.00 & 0.00 & 0.00 & 0.00 & 0.00 & 5.56 \\
\hline Crni lug & 0.00 & 0.00 & 0.00 & 0.00 & 0.00 & 0.00 \\
\hline Ritske sume & 0.00 & 2.2 & 2.66 & 0.00 & 0.00 & 3.21 \\
\hline Zvezdara & 0.00 & 0.00 & 1.19 & 0.00 & 0.00 & 6.61 \\
\hline
\end{tabular}




\subsection{Total number of fungi}

In forest soil this physiological group of microorganisms mostly engages in cellulose, hemicelluloses and lignin matter degradation. Under aerobic conditions, cellulose and hemicelluloses transformations are conducted turbulently, but not up to the end-products, so they comprise humus indirectly, through synthesized microbiological substance (mucilage). Microorganisms of this physiological group were not present in large numbers on synthetic (Table 6) and on Czapek's agar (Table 7). The exceptions were coniferous forests at locations in Trešnja and on Kosmaj, as well as Bojčinska šuma and Crni lug, where their number was considerably greater. This suggests a significant role of fungi in humus biosynthesis at these locations.

Table 6. Total number of fungi on synthetic agar (1000 pcs / $1 \mathrm{~g}$ of dry soil)

\begin{tabular}{|l|r|r|r|r|r|r|}
\hline Locations & \multicolumn{1}{|c|}{ July } & September & October & November & January & \multicolumn{1}{c|}{ May } \\
\hline Kosutnjak & 13.64 & 26.86 & 17.59 & 16.55 & 38.61 & 23.79 \\
\hline Miljakovac & 14.32 & 24.69 & 9.45 & 22.75 & 12.71 & 21.95 \\
\hline Banjica & 12.54 & 4.61 & 14.58 & 23.39 & 27.03 & 24.91 \\
\hline Baba Velka & 8.46 & 29.48 & 10.40 & 5.41 & 63.16 & 25.87 \\
\hline Jajinci & 16.39 & 26.20 & 13.09 & 16.78 & 15.03 & 58.64 \\
\hline Avala & 11.58 & 9.43 & 18.60 & 6.81 & 7.95 & 6.11 \\
\hline Tresnja & 32.61 & 43.46 & 18.32 & 23.58 & 28.64 & 19.41 \\
\hline Kosmaj & 13.66 & 40.27 & 17.96 & 21.78 & 6.02 & 33.24 \\
\hline Gorica & 20.24 & 45.26 & 9.24 & 10.54 & 30.42 & 7.49 \\
\hline Lipovica & 95.46 & 65.67 & 41.56 & 34.21 & 16.47 & 9.37 \\
\hline Laz.sume & 27.51 & 27.31 & 14.52 & 10.90 & 7.91 & 33.44 \\
\hline Makis & 28.43 & 16.42 & 11.29 & 8.98 & 12.27 & 31.12 \\
\hline Ada Ciganlija & 10.29 & 13.90 & 0.00 & 9.02 & 14.15 & 15.11 \\
\hline Auto put & 13.82 & 3.19 & 12.15 & 17.18 & 3.64 & 17.51 \\
\hline Obrenovacki zabran & 2.35 & 1.04 & 10.82 & 4.89 & 21.11 & 11.57 \\
\hline Bojcin & 40.04 & 17.83 & 23.42 & 36.69 & 27.61 & 57.05 \\
\hline Crni lug & 11.31 & 13.89 & 46.26 & 18.68 & 12.42 & 55.12 \\
\hline Ritske sume & 17.17 & 0.00 & 19.96 & 11.99 & 9.15 & 19.83 \\
\hline Zvezdara & 16.42 & 6.37 & 10.73 & 3.86 & 11.95 & 15.72 \\
\hline
\end{tabular}

Table 7. Total number of fungi on Czapek's agar (1000 pcs / $1 \mathrm{~g}$ of dry soil)

\begin{tabular}{|l|r|r|r|r|r|r|}
\hline Locations & \multicolumn{1}{|c|}{ July } & September & October & November & January & \multicolumn{1}{c|}{ May } \\
\hline Kosutnjak & 28.60 & 9.34 & 7.03 & 21.64 & 38.61 & 2.79 \\
\hline Miljakovac & 13.02 & 18.19 & 13.65 & 13.65 & 11.51 & 5.16 \\
\hline Banjica & 13.79 & 28.81 & 8.96 & 24.63 & 14.21 & 0.00 \\
\hline Baba Velka & 19.37 & 11.79 & 4.62 & 0.00 & 6.57 & 2.87 \\
\hline
\end{tabular}




\begin{tabular}{|l|r|r|r|r|r|r|}
\hline Locations & \multicolumn{1}{|c|}{ July } & September & October & November & January & \multicolumn{1}{c|}{ May } \\
\hline Jajinci & 2.34 & 25.06 & 2.38 & 24.52 & 3.76 & 5.58 \\
\hline Avala & 11.58 & 0.00 & 10.94 & 5.45 & 9.27 & 24.45 \\
\hline Tresnja & 42.98 & 34.31 & 4.58 & 7.39 & 9.11 & 0.00 \\
\hline Kosmaj & 35.51 & 48.81 & 10.26 & 15.05 & 13.55 & 6.39 \\
\hline Gorica & 28.58 & 18.77 & 16.17 & 17.84 & 22.13 & 3.75 \\
\hline Lipovica & 62.19 & 12.51 & 23.22 & 26.83 & 23.34 & 2.68 \\
\hline Laz.sume & 41.39 & 52.67 & 16.94 & 4.47 & 26.36 & 7.72 \\
\hline Makis & 33.38 & 0.00 & 25.99 & 28.23 & 1.53 & 9.22 \\
\hline Ada Ciganlija & 18.59 & 10.69 & 18.19 & 2.26 & 17.29 & 17.47 \\
\hline Auto put & 5.76 & 10.47 & 7.73 & 9.66 & 3.64 & 18.31 \\
\hline Obrenovacki zabran & 16.44 & 13.51 & 12.98 & 2.45 & 2.81 & 37.02 \\
\hline Bojcin & 42.57 & 4.48 & 17.57 & 43.49 & 11.38 & 30.61 \\
\hline Crni lug & 45.26 & 3.79 & 70.05 & 22.99 & 6.90 & 58.86 \\
\hline Ritske sume & 11.45 & 2.20 & 29.28 & 2.66 & 3.05 & 33.69 \\
\hline Zvezdara & 22.86 & 3.18 & 24.38 & 15.42 & 1.33 & 26.46 \\
\hline
\end{tabular}

\section{CONCLUSION}

In the soil of deciduous forests at all locations investigated ammonification processes continue unhindered, which is suggested by the large numbers of ammonifying microorganisms. Due to smaller numbers of ammonifying organisms, weaker inflow of organic matter and its elemental composition (coniferous species, oaks and poplars) as well as due to the $\mathrm{C} / \mathrm{N}$ ratio, in forest parks which are anthropogenically impaired, ammonification processes are slow. Humification processes are predominant in the soil of all locations investigated. Small numbers of actinomycetes at all locations imply that dehumification processes are performed with difficulties and the formation of easily accessible plant assimilatives is reduced. Preliminary research suggests that the ammonification process is most significant in both humus synthesis and degradation for creation of plant assimilatives (nitrogen, phosphorus, sulphur, etc.); therefore the measures undertaken must be focused on ensuring normal and regular course of such processes.

Selective logging in mixed stands should stimulate the selection of species that will provide detritus of favorable humus composition. By opening canopies, conditions are created for inflow of sunlight and soil warming. Adequate temperatures of the soil and its water and air patterns have favorable effects on the microbiological processes which will stimulate the inflow of plant assimilatives and thus growth and yield.

Soil microorganisms and processes they participate in are causally related to the environmental conditions. Soil microorganisms are very susceptible to any anthropogenic influence, which results in their degradation. 
Monitoring of the numbers and activities of forest soil microorganisms ought to enable our timely identification of disorders in the relevant ecosystem and allow us to implement certain forestry and cultivation measures for the purpose of indirect prevention of further degradation. In order to infer a conclusion on the tendency, direction and extent of the soil degradation, and thus plant ecosystem degradation, monitoring ought to be continued. Based on the results of years long monitoring of the microbiological activity of forest soil, practical solution will be proposed in the future as to what systems at relevant locations can be improved by applying forestry cultivation measures. In this way, activities of soil microbe communities will contribute to the stability and sustainability of the forest ecosystems in the long term.

\title{
REFERENCES
}

Raičević, V., Lalević, B., Kljujev, I., Petrović, J. (2010) Ekološka mikrobiologija, univerzitetski udžbenik, Univerzitet u Beogradu

Sylvia, D.M., Fuhmann, J.J., Hartel, P.G., Zuberer, D.A.(2005) Principles and applications of soil microbiology, $2^{\text {nd }}$ edition, Pearson Prentice Hall, New Jersey

Varman, A.H., Evans, M.G. (2000) Environmental Microbiology, Manson Publishing Ltd, London, UK

Atlas, R.M., Horowitz, A., Krichevsky, M., Bej, A.K. (1991) Response of microbial populations to environmental disturbance, Microb. Ecol. 22

Tešić. Ž. (1968) Mikrobiologija šumskih zemljišta. Naučna knjiga. Beograd.

Mišustin, E.N. (1956) Mikroorganizmi i plodnost zemljišta-prevod sa ruskog- Zadružna knjiga-Beograd.

\section{MICROBIOLOGICAL ACTIVITY OF THE FOREST SOIL IN THE AREAS WITHIN THE TERRITORY OF BELGRADE}

\author{
Milorad VESELINOVIĆ, Vesna GOLUBOVIĆ-ĆURGUZ, Suzana MITROVIĆ, \\ Dragana DRAŽIĆ, Nevena ČULE, Biljana NIKOLIĆ, Đorđe JOVIĆ
}

\section{Summary}

Forest ecosystems rely on the process of natural matter ad energy circulation for their survival. Within the process of matter circulation, soil microorganisms play a decisive role in the biological circulation of nutrition elements, i.e. plant assimilatives, through the process of organic matter (detritus) degradation via biosynthesis (humification) and mineralization (dehumification), releasing plant assimilatives. In this way, nutritive matter is returned to the forests, allowing the plants to survive and develop.

Development of appropriate physiological groups of microorganisms participating in such processes and their biological activity are prerequisites of the forest ecosystem stability. Their function in certain forest soil types with varying anthropogenic influence is a significant stability factor for such soils. 
From May 2010 to April 2011, research in microbiological activity of forest soil was conducted at 19 locations of forested areas in both state and private ownership in the territory of Belgrade.

Preliminary research suggests that the ammonification process is most significant in both humus synthesis and degradation for creation of plant assimilatives (nitrogen, phosphorus, sulphur, etc.); therefore the measures undertaken must be focused on ensuring normal and regular course of such processes.

Monitoring of the numbers and activities of forest soil microorganisms ought to enable our timely identification of disorders in the relevant ecosystem and allow us to implement certain forestry and cultivation measures for the purpose of indirect prevention of further degradation. In order to infer a conclusion on the tendency, direction and extent of the soil degradation, and thus plant ecosystem degradation, monitoring ought to be continued.

\title{
MIKROBIOLOŠKA AKTIVNOST ŠUMSKIH ZEMLJIŠTA NA PODRUČJU BEOGRADA
}

\author{
Milorad VESELINOVIĆ, Vesna GOLUBOVIĆ-ĆURGUZ, Suzana MITROVIĆ, \\ Dragana DRAŽIĆ, Nevena ČULE, Biljana NIKOLIĆ, Đorđe JOVIĆ
}

\section{Rezime}

Na procesima kruženja materije i energije u prirodi šumski ekosistemi zasnivaju svoj opstanak. U tom procesu zemljišni mikroorganiozmi imaju odlučujuću ulogu u biološkom kruženju elemenata ishrane - biljnih asimilativa. Oni se odvijaju kroz proces degradacije organske materije (stelje) biosintezom (humifikacijom) i mineralizacijom (dehumifikacijom) oslobađajući biljne assimilative. Na taj način se šumi vražaju hranljive materije koje omogućavajući biljkama u šumi da opstanu i da se razvijaju.

Razvoj odgovarajućih fizioloških grupa mikroorganizama koji učestvuju u ovim procesima i njihova biološka aktivnost je predpostavka stabilnosti šumskih ekosistema. Njihovo funkcionisanje u određenim tipovima šumskog zemljišta različitog antropogenog uticaja, značajno je za stabilnost takvih zemljišta.

U periodu maj 2010. godine i april 2011. godine na području Beograda vršena su istraživanja mikrobiološke aktivnosti šumskih zemljišta na 19 lokaliteta pod šumom u državnom i u privatnom vlasništvu

Preliminarna istraživanja ukazuju da je proces amonifikacije, najznačajniji kako u sintezi tako i u razlaganju humusa za stvaranje biljnih asimilativa (azota, fosfora, sumpora i dr.), pa i mera koje primenjujemo moraju biti usmerene da se ovakvi procesi odvijaju normalno. Monitoring broja mikroorganizama i njihove aktivnosti u šumskim zemljištima treba da nam omogući da na vreme uočimo poremećaje u tom sistemu i da određenim šumsko uzgojnim merama posrednim putem sprečimo dalju degradaciju. Da bi se doneo zaključak o tendenciji, pravcu i stepenu degradacije zemljišta, a samim tim i ispitivanih šumskih ekosistema, istraživanja treba nastaviti. 
